\title{
Influence of Project Management Certification on Project Managers' Career
}

\author{
Tomislav Rastovski ${ }^{1, *}$
}

\author{
${ }^{1}$ University College Algebra, 10000 Zagreb, Croatia \\ *Corresponding author. Email: tomislav.rastovski@gmail.com
}

\begin{abstract}
Project Management as profession has been rapidly developing in last few decades. That has been followed by many different Certifications developed by different organizations. The aim of research was to explore how Project Management Certificate can influence on Project Managers' career. The qualitative research was made within 35 Project Managers from 15 different countries. Research was conducted using grounded theory method for identification of the major codes that are representing areas where knowledge and skills required for Project Management Certificate can affect a Project Managers' career. The results of conducted research show that there is not the same level of importance of all identified codes and confirm that the Project Management Certification has positive influence on Project Managers' Career.

Keywords: Project Manager; Career Path; IPMA; PMI; Competence
\end{abstract}

\section{INTRODUCTION}

Project Management as profession has been rapidly developing in last few decades [1]. That has been followed by many different certificates developed by different organizations. Two leading international project management organizations, the International Project Management Association (IPMA) and the Project Management Institute (PMI), have developed the IPMA Competence Baseline (ICB) [2] and the Project Manager Competence Development Framework (PMCD) [3] where the Project Managers' competencies are defined. There are also other organizations that have their own certification system (Australian Institute of Project Management [4], Association for Project Management - the chartered body for the project profession [5], etc.). Certification is a popular way for project managers to point out their proficiency and also for hiring managers to filter job applications.

\section{LITERATURE REVIEW}

The role of project manager is one of the most challenging tasks in any organization because it involves understanding and good coordination of different areas of profession and science which requires exceptional interpersonal skills [6]. The skill sets required for success in the workplace have changed dramatically in the past few years [7]. Most employers expect their employees to demonstrate a mixture of skills, including technical project management competencies, business domain knowledge, team management, communication, interpersonal skills, cognitive aptitude and leadership behaviours supported by project management education [8] [9]. The lack of research concerning the effects of certification programs and the professionalization of occupations has been highlighted career education [10]. On the other hand, research in procurement and contract management has explored the value of certification to both employers and individuals [11]. The biggest benefit of the globally accepted competency framework would have international companies and the projects itself because it clearly defines standards and certifications in project management that enables development of careers in project management [12]. Interest in project management competencies has led to the development of standards-based on knowledge and experience in project management used for assessment, development and certification [13]. The research [14] concludes that project manager certification is not a guarantee of good project execution but is certainly used as a very important indicator for Project Managers' tasks performance during project realization. Also, in the research [15] authors come to the conclusion that the research results provide concrete evidence of relations between ICB 3.0 competences and success of the project. Therefore, advanced certification systems do not only assess knowledge but also focus on competencies and experience gained through project execution [2]. The IPMA 4-L-C System operates within three domains (project, program and portfolio) and defines four levels: IPMA level A (Certified Project / Program / Portfolio Director), IPMA level B (Certified Senior Project / Program / Portfolio Manager), IPMA level C (Certified Project Manager) and IPMA level D (Certified Project Management Associate) [2]. PMI System operates also within domains (project, program and portfolio) and defines: PfMP (Portfolio Management Professional), PgMP (Program Management Professional), PMP (Project Management Professional), CAPM (Certified Associate in Project Management) and few other certificates specific to some PM areas [3]. Since the subject of this research is 
Project Manager, not Program or Portfolio Manager, all respondents will need to have one of following certificate: IPMA levels C, IPMA level B or PMP.

\section{PROBLEMS AND METHODOLOGY}

The project manager's role is one of the most challenging jobs in any organization because it requires a broad understanding of the various areas that must be coordinated and therefore a project manager has to possess a wide spectre of competencies [6] [16]. Most employers expect their employees to demonstrate a mixture of technical skills, business domain knowledge, team management, communication, interpersonal skills, cognitive attitude and leadership behaviour's supported by project management education [8] [9]. The various areas that Project Manager has to understand and apply can be grouped as contextual, behavioural and technical competences [17] or Perspective, People and Practice [2]. IPMA and PMI standards are globally present in more than 70 countries around the world and organizations together have more than a million certified project managers all over the world, so selected respondents have one of the following certificates: IPMA level C, IPMA level B or PMP by PMI.

With the aim of exploring influence of Project Management Certificate on Project Managers' Career, during 2020, a qualitative empirical research was conducted within 35 Project Managers from 15 different countries. Project Managers were participating in one-hour in-depth interviews and the collected data were analysed using a grounded theory method [18]. As a result, five major codes that have influence on project mangers' career were identified:

1. lack of skills and knowledge in Project Management acquired through basic education,

2. better project performance trough continual professional development,

3. better job opportunity and higher salary,

4. ability to manage complex projects,

5. legislation and the employer.

In order to explore various reasons for obtaining Project Management Certificate and its influence on Project Managers' career, qualitative research have been undertaken and the details are given as follows.

\section{RESULTS AND DISCUSSION}

In this section, results will be organized around constructed major codes with the quotes adequately explaining them.

\subsection{Lack of skills and knowledge in Project Management acquired through basic education}

Project Managers have different basic education. Some of them have technical background as engineers (IT,
Construction, Machinery, etc.), the other business and management, social or environmental sciences, etc. To all of them is in common that they have received little or nothing knowledge about Project Management through their basic education. According to the interview, results can be classified into 3 groups: behavioural (People based), technical (Project based) and contextual (Perspective based) skills and knowledge [2] [17].

\subsubsection{Behavioural skills and knowledge}

During research it was found out that respondents who have technical background (e.g., engineers) have at least behavioural skills and knowledge of all respondents. The main reason of that is because they were programmers or construction engineers (usually experts for some specific technical area) and through the years they have become a project manager:

- I have been programmer for ten years and my boss decided to give me a role of Project Manager. I have never done that job before. When I have started to manage a small team, I didn't feel capable of managing people. Now I have learned by experience and participation of some Project Management courses during preparation for IPMA certification exam.

- During study on technical university, I didn't have any subject regarding "soft skills". During preparation for PMP exam I have participated different trainings (including "soft skills") which have helped me to improve my skills.

Other respondents had social science background (mostly economy and law) and they had better knowledge from this area than engineers. Their main problem was insufficient experience:

- I know the methods how I should resolve the conflict, but it is much easier said than done. When I was younger, I had a problem because you can never satisfy both sides, but now after ten years of experience there is no problem anymore.

- I have a master's degree in project management, I have passed a lot of exams from all project management areas, but the main problem was that during education we didn't have chance to implement that knowledge and develop our skills.

Behavioural knowledge gained through education is not sufficient for managing people. Education should include practical parts, such as trainings or coaching based on the real case scenarios.

\subsubsection{Technical skills and knowledge}

Technical knowledge and skills are mostly implemented into educational system in those institutions that have some subject from Project Management field, according to the respondents' answers. That includes definition of project scope, time and cost. Also, definition of project 
requirements, procurement procedures, techniques for planning, monitoring and control of project executions, managing of risks and stakeholders. Most of respondents are familiar with knowledge which they have received within their educational institutions, but their lack of skills and abilities is spotted during research:

- I had subject Project Management during my education, but we have worked in a team on a defining all aspects of one project. I know all the areas I have to define, but I miss the skills by using some techniques from that are used on real projects through some software. By my opinion, I haven't received enough skills in my educational institution.

- During my basic education, I have worked voluntary on one project for NGO. All the knowledge that I have received at my University, I have applied on actual NGO project. That was winning combination.

There are differences between educational institutions. Some of them organize for their students at least simulation of Project Managers' role on a team cases or voluntary work on some projects to practice their skills and abilities.

\subsubsection{Contextual skills and knowledge}

Use of contextual skills and knowledge depends on a type of a project. In organizational projects which are managed within some private organization very important are skills and knowledge for aligning projects with company strategy (mission and vision, determination of critical success factors and key performance indicators) and power and influence that some functions within organization can have on project execution and deliverables:

- $\quad$ Some of functional directors, which have needed the same resources as I in my project, have used their power and influence to block and use those resources for their project. That happened because of my lack of knowledge in organizational structures and not insisting to formalize a role of Project Manager within organization.

Culture is also very important contextual element often not taken seriously enough:

- I have managed dozens of projects within Europe and we got one project in Indonesia. I have applied the same methods for managing project as in Europe, but I had a serious problem because I didn't adjust to their culture and principles of managing projects.

Standards and regulations are also recognized as very important contextual element during research:

- During my education for an engineer, I have heard about and learned different standards but for managing project I need much wider spectrum of standards and regulations than I needed as engineer.
- $\quad$ Standards and Government regulations were very important part of project that I have managed. Since I didn't have enough knowledge, I have hired an expert which has been a team member until the end of the project. After that project I have decided to focus my continual professional development into Standards and Government regulations direction since this is very important part of my projects.

Certificates requires certain number of months or working hours of experience working as a project manager so certification is definitely moment that will force individuals to empower their Project Management competences. Lack of skills and knowledge in Project Management acquired through basic education can be upgraded by knowledge, skills and abilities obtained during preparation for certification process and passing certification exam.

\subsection{Better project performance trough continual professional development}

According to the previous section, those who lack knowledge from particular Project Management field, will adequately fulfil that gap trough continual professional development. IPMA and PMI certificate holders have obligation of continuous education and they have to prove it through CPD (by IPMA) and PDU (by PMI) points:

- Since I have pass certificate for Project Management Professional (PMP), I had to renew my certificate every 3 years. To do that I need to collect certain amount of PDU points through self-learning and trainings. I have participated few trainings where I have improved my skills for planning and monitoring projects. Now I use those methods for managing projects.

- Since I am Certified Senior Project Manager (IPMA B), I have to collect 175 CPD points through continual education in Project Management. I choose practical trainings focused on areas that I am less familiar with.

- Before certification I have shared new knowledge with my co-workers and participation on Project Management conferences. After this obligation for re-certification, I have to admit that I have improved my leadership competences by participation at few "soft skills" training in a last few year.

Respondents also mentioned that it is big obligation, but on the other hand they are happy because they follow all new trends, standards and methodology development in Project Management which are very useful in their everyday job.

\subsection{Better job opportunity and higher salary}

During interviews, according to the answers it was clear that respondents were motivated with the better job 
position when they accomplish some certificate for Project Manager:

- At the beginning of my career, I have worked as Project management assistant. Having a Project Management certificate enabled me to work as a Project Manager.

- I am working in a consulting company and some of our top clients have employees with PMI certificate. After I became PMP, my boss always assigns me to our top clients.

Few of them mentioned connection between Project Management Certificate and salary:

- Before I became IPMA level C, I have usually managed small and simple projects. After certification, my boss gave me a better job position which has, by itself, higher salary.

- For me there is no difference in the salary, either you have or not Project Management Certificate because I work for the Government. But Certificate can be advantage if you are applying for a job in foreign companies where the salary is much higher the same job than if you work for Government.

Other respondents also had similar answers. They have confirmed that there is positive connection between Project Management Certificate and better job opportunity and indirectly higher salary.

\subsection{Ability to manage complex projects}

This code was identified by Senior Project Managers (IPMA Level B and some PMP's):

- $\quad$ Since I work in company that offers supervision and project management services, I consider very important to have certificate which proofs that I am capable to manage complex projects. That is very important for our company because it can obtain us extra points on a public tender procedure.

- $\quad$ During IPMA Level B assessment procedure, I have revealed project management areas with which I was not familiar enough. After certification I have participated few trainings focused to those areas and now, I feel more capable to manage those areas in complex projects.

This code was not identified by all respondents. It was identified only by experienced Project Managers, which are freelances and/or they work on a big project as Professional Project Mangers.

\subsection{Obligation by legislation or the employer}

\subsubsection{Legislation}

Legislation is different from country to country. In the Republic of Croatia management of the construction project financed with public money value more than $10 \mathrm{mil}$. HRK has to be managed by professional Project Manager that can prove his knowledge and skills by diploma or Project Management Certificate:

- Since I work on government project, total value more than 50 mil. HRK, due to Croatian legislation, I had to take a Certificate for Project Manager.

Legislation is different from country to country. Respondents from other countries didn't mention connection between project management certificate and legislation.

\subsubsection{Employer}

Few respondents mentioned that employer asked employees to take and pass certificate:

- My employer asked me to take certificate so that we can tender for the project where the certificate for Project Manager is required.

- When I was seeking for a new job, I couldn't apply for it because Project Management Certificate (IPMA C or PMP) was obligatory requirement.

Nowadays, more and more companies have Project Management Certificate as mandatory requirement for a position of Project Manager. That was positively confirmed during interviews by those respondents that were seeking for a new job.

\section{CONCLUSION}

After conducted qualitative research it is possible to conclude that there exists connection between Project Management Certificate and Project Managers' Career. During research there were identified 5 major codes but not all of the codes are identified by all respondents. Some respondents didn't mention "Legislation" or "Ability to manage complex projects”, but all of respondents have mentioned "Lack of knowledge in Project Management acquired through basic education", "Better project performance trough continual professional development" and "Better job opportunity". Not all of the codes are mentioned by the same level of importance, but all respondents are aware of existence of those codes and that can affect their career path in smaller or larger scale. According to those three major codes Project Management Certification has positive influence on Project Managers' Career. Of course, this research included different countries and regions with different culture, so 
recommendation for further researches is to limit research to specific areas and specific industries.

\section{REFERENCES}

[1] T. Blomquist, A.D. Farashah, J. Thomas, "Feeling good, being good and looking good: Motivations for, and benefits from, project management certification.”, International Journal of Project Management vol. 36, iss. 3, pp. 498-511, 2018.

[2] IPMA, Individual Competence Baseline for Project, Programme \& Portfolio Management - 4th Version, Nijkerk: International Project Management Association, 2015.

[3] PMI, Project manager competency development framework - Third Edition, Newtown Square, PA, USA: Project Management Institute Inc., 2017.

[4] AIPM, Project management certification, Accessed on: Nov. 14, 2020. [Online]. Available: https://www.aipm.com.au/certification/nationalcertification

[5] APM, Chartered Project Professional, Accessed on: Nov. 14, 2020. [Online]. Available: https://www.apm.org.uk/chartered-standard/

[6] K. Ahsan, M. Ho and S. Khan, "Recruiting Project Managers: A Comparative Analysis of Competencies and Recruitment Signals From Job Advertisements, “ Project Management Journal, vol. 44, pp. 36-54, 2013.

[7] M. Alam, A. Gale, M. Brown and A.I. Khan, "The importance of human skills in project management professional development", International Journal of Managing Projects in Business, vol. 3, pp. 495-516, 2010.

[8] V.G. Lizunkov, V.I. Marchuk and E.A. Podzorova, „Identification of Criteria, Features of Development and Level of Economic and Managerial Competencies of Bachelors in Mechanical Engineering“, Procedia Social and Behavioral Sciences, vol. 206, pp. 388-393, 2016.
[9] C. C. Silva de Araújo, C. Drebes Pedron, „IT project manager competencies and IT project success: a qualitative study “, Organisational Project Management, vol. 2 pp. 53-75, 2015.

[10] K.R. Bartlett, „A theoretical review of the signalling role of certifications in career and technical education“. Proceedings of annual conference of the Association for Career and Technical Education Research, Atlanta, GA., 2012.

[11] S. Abutabenjeh, The Value of Procurement Certification. Old Dominion University, Virginia, United States (Unpublished doctoral dissertation), 2015.

[12] L. Crawford, Project management competence for the new millennium. Proceedings of 15th World Congress on Project Management, London, 2000.

[13] L. Crawford, Senior management perceptions of project management competence. International Journal of Project Management, vol. 23, pp. 7-16., 2005.

[14] R. Müller, J.R. Turner, The Influence of Project Managers on Project Success Criteria and Project Success by Type of Project. European Management Journal, vol. 25, pp. 298-309., 2007.

[15] M.-M. Nahod, M. Vukomanović, M. Radujković, The Impact of ICB 3.0 Competences on Project Management. Procedia - Social and Behavioral Sciences, vol. 74, pp. 244 - 254., 2013.

[16] L. Geoghegan and V. Dulewicz, “Do project managers' leadership competencies contribute to project success?" Project Management Journal, vol. 39, pp. 5867, 2008.

[17] IPMA, Individual Competence Baseline for Project, Programme \& Portfolio Management - 3th Version, Nijkerk: International Project Management Association, 2006 .

[18] J. Corbin and A. Strauss, Basics of qualitative research: Techniques and procedures for developing Grounded Theory, Thousand Oak: Sage Publications, 2008. 